\title{
Editorial
}

\section{On the roles of scientists, press officers and journalists}

\section{Emma Weitkamp}

\begin{abstract}
This issue of the Journal of Science Communication raises a number of questions about the ways that new scientific research emerges from research institutions and in particular the role played by scientists, press officers and journalists in this process. This is not to suggest that the public don't play an equally important role, and several articles in this issue raise questions about public engagement, but to explore the dynamics at play in one specific arena: that of news production. In this editorial I explore the increasing reliance of science journalists on public relations sources and consider what questions this raises for science communication.
\end{abstract}

This issue of the Journal of Science Communication raises a number of questions about the ways that new scientific research emerges from research institutions and in particular the role played by scientists, press officers and journalists in this process. This is not to suggest that the public don't play an equally important role, and several articles in this issue raise questions about public engagement, but to explore the dynamics at play in one specific arena: that of news production. Even in our increasingly fragmented digital world, most Europeans report learning about science from media, with $65 \%$ hearing about science on TV, $35 \%$ using the internet to find information on science and technology subjects and 33\% mentioning newspapers as a source of science and technology information [1]. Access to TV and newspapers is mediated by journalists and sometimes also by the press office of the institution for which the researcher works. Other platforms, including many digital platforms such as blogs and social media, allow scientists to communicate directly with the public, though this may still be a largely one way conversation. Yet concerns have been raised both about an increasing medialization of science [2] and the growing dominance of institutional sources (e.g. press officers) in the news construction process [3].

Tensions between public relations and science communication are tackled in the commentary 'Public Communication from Research Institutes: Is it Science Communication or Public Relations?' organised by Rebecca Bru Carver and published in this issue. The commentaries take a critical look at the role of media relations within scientific organisations, exploring the ways that the media contribute to the spread of knowledge within the scientific community (Shipman), an issue which is also addressed in the research paper 
by Mahrt and Pushmann in this issue, and considering how the roles of science journalists could change to make better use of institutional PR materials (Autzen). Acknowledging the growing pressures on science journalists to produce increasing volumes of science news, Autzen suggests that we should accept 'cut and paste' journalism in order to enable science journalists to focus more on the traditional role of the media as watchdog, holding the institutions of science to account; in essence, Autzen suggests that we stop haranguing the media for cut and paste journalism and accept that press officers are perfectly capable of writing straightforward, single source news stories for public consumption. While I do agree with Autzen that press officers have the technical skill to write such stories (they are after all often former journalists), I'm not sure that I want universities and research institutes producing the news. They are, after all, self-interested organisations that seek to promote their own agendas.

Of course, Autzen is not suggesting that press office materials would be published without some sort of editorial control. Instead, she is suggesting that journalists should not be criticised for using these materials, particularly if it frees up time for them to pursue more contentious issues. The Washington Post took this tactic earlier this year. I don't know how it was received by the readers (or even if they noticed that a proportion of the science and health news was taken straight from press releases), but it did cause a stir in the journalistic community [4]. The problem is not one of clarity of writing or structure of the story, these the press officers do extremely well. They have to for their press releases to stand a chance of making it on a journalist's shortlist. The problem, for the Washington Post, was quality control. Several of the stories that made it through the editorial selection process were downright silly (which is not uncommon but does leave a crack for critics when you try something that appears lazy, such as running press releases as news). Raeburn used this crack in credibility to point out that the problem with press releases lies in their institutional purpose - to frame the story to suit the organisation. Nine times out of 10, this may be a benign framing, even one the journalist agrees with. But that is not always the case. Take the recent press release from Newcastle University on organic foods. ${ }^{1}$ This press release reports a new study suggesting the health benefits of organic foods. But this is a controversial area; the journalists reporting the story made the effort to speak with other experts who raised questions about the study. Journalists reported the story, but not uncritically adding context and information from a variety of other sources. In our current overstretched media environment, marketing stories do slip under the radar of science journalists through carefully crafted science news releases, as my study shows [3]. If marketing efforts occasionally make it past the beady eyes of journalists now, then surely even more would slip through a news system geared to accepting (albeit critically) press releases as news. How are we, readers unpractised in spotting 'spun stories', and who do not have day to day contact with researchers and press officers, to know which stories need to be treated with caution?

\footnotetext{
${ }^{1}$ http://www.ncl.ac.uk/press.office/press.release/item/new-study-finds-significant-differences-betweenorganic-and-non-organic-food.
} 
I certainly agree with Autzen that well-crafted press releases and efficient, helpful press officers do offer a useful service to science journalists. After all, they cannot possibly scan all the original research published in any given week. And journalists should be holding research organisations, individual scientists and others involved in the 'industry' that is science to account. But I do not think that cut and paste journalism is the solution to media staffing issues. Instead, we need to re-educate the reader to the value of what they consume. In the end, you get what you pay for and good journalism costs money. We should ask ourselves whether we are prepared to pay for that craft. If we aren't, then university press officers may well be writing our science news.

\section{References}

[1] TNS Opinion and Social (2013), Responsible Research and Innovation (RRI), Science and Technology, Special Eurobarometer 401, available from: http://ec.europa.eu/public_opinion/archives/ebs/ebs_401_en.pdf [accessed 21/1/14].

[2] S. Rödder (2011), “Science and the Mass Media - 'Medialization' as a New Perspective on an Intricate Relationship”, Sociology Compass 5(9): 834-845.

[3] E. Weitkamp and T. Eidsvaag (2014), "Journalism Practice: Agenda Building in Media Coverage of Food Research”, Journalism Practice, DOI: 10.1080/17512786.2013.865966.

[4] P. Raeburn (2014), "Want your university press release reprinted in the Washington Post? Heres How”, KSJ Tracker, https://ksj.mit.edu/tracker/2014/02/want-your-university-press-release-repri/ [accessed 21/8/14].

\section{Author}

Dr. Emma Weitkamp is an Associate Professor in Science Communication at the University of the West of England, Bristol where she teaches on an MSc in Science Communication and provides training in science communication for practitioners and Ph.D. students. Emma has recently been appointed as Editor in Chief of JCOM.

E-mail: Emma.Weitkamp@uwe.ac.uk.

How TO CITE: E. Weitkamp, "On the roles of scientists, press officers and journalists”, JCOM 13(03)(2014)E. 